\title{
Comparison of Fatty Acid Compositions in Birds Feeding in Aquatic and Terrestrial Ecosystems
}

\author{
M. I. Gladyshev ${ }^{a, b}$, O. N. Popova ${ }^{c}$, O. N. Makhutova ${ }^{a}$, T. D. Zinchenko ${ }^{d}$, L. V. Golovatyuk ${ }^{d}$, \\ Yu. A. Yurchenko ${ }^{c}$, G. S. Kalachova ${ }^{a}$, A. V. Kylove ${ }_{1}^{e}$, and N. N. Sushchik ${ }^{a, b}$ \\ ${ }^{a}$ Institute of Biophysics, Siberian Branch, Russian Academy of Sciences, Akademgorodok 50/50, Krasnoyarsk, 660036 Russia \\ ${ }^{b}$ Siberian Federal University, pr. Svobodnyi 79, Krasnoyarsk, 660041 Russia \\ ${ }^{c}$ Institute of Systematics and Ecology of Animals, Siberian Branch, Russian Academy of Sciences, \\ ul. Frunze 11, Novosibirsk, 930091 Russia \\ ${ }^{d}$ Institute of Ecology of the Volga River Basin, Russian Academy of Sciences, ul. Komzina 10, Tolyatti, 445003 Russia \\ e Papanin Institute for Biology of Inland Waters, Russian Academy of Sciences, Yaroslavl oblast, Borok, 152742 Russia \\ e-mail: michailgladyshev@yahoo.com,pc@eco.nsc.ru,makhutova@ibp.krasn.ru,tdz@mail333.com,gollarisa@mail.ru, \\ yurons@ngs.ru,kalach@ibp.ru,krylovamik@gmail.com,labehe@ibp.ru \\ Received October 05, 2015; in final form, November 02, 2015
}

\begin{abstract}
Fatty acid (FA) contents and compositions in the pectoral muscles of 18 bird species from Novosibirsk, Volgograd, and Yaroslavl oblasts were studied. Three groups of birds that had significantly different FA compositions were distinguished based on a multivariate statistical analysis: Passeriformes, Columbiformes, and a group of waterfowl and waterbird species (Charadriiformes, Anseriformes, Podicipediformes, and Ciconiiformes). The highest content of physiologically important docosahexaenoic FA (22:6n-3, DHA), which is considered a marker of aquatic food, was surprisingly found in the biomass of Passeriformes, which are terrestrial feeders, rather than in the biomass of waterfowls and waterbirds. It was suggested that Passeriformes species had the ability to synthesize large quantities of DHA from short-chain omega-3 FAs, which is rare among animals.
\end{abstract}

Keywords: polyunsaturated fatty acids, birds, aquatic ecosystems, terrestrial ecosystems

DOI: $10.1134 /$ S1995425516040065

\section{INTRODUCTION}

As is known, one of the key problems of ecology is to study the fluxes of matter and energy in natural ecosystems. In recent years, along with the traditional study of these fluxes in food webs of individual ecosystems, there has been a significant growth in attention of ecologists to the processes of transport of organic carbon between ecosystems, including aquatic and terrestrial ecosystems (Baxter et al, 2005; Ballinger and Lake, 2006; Gratton and Vander Zanden, 2009). The amount of organic matter entering with biogenic fluxes from water to land can be very high. For example, the share of the biomass of freshwater organisms in the annual ration of forest aviafauna in Japan surpasses 25\% (Nakan and Murakami, 2001). Moreover, the products of water ecosystems can give not only a large quantitative, but also an important qualitative contribution to the feeding of terrestrial consumers. In aquatic ecosystems, diatoms, dinophytes, and cryptophytes synthesize de novo a large amount of longchain polyunsaturated fatty acids (FAs) of omega-3 family (PUFAs), namely eicosapentaenoic acid (20:5n-3, EPA) and docosahexaenoic acid (22:6n-3,
DHA), which are essential food components in most animals, both aquatic and terrestrial ones, including humans (Arts et al., 2001). Since terrestrial organisms (some bacteria, fungi, and animals, but not higher plants!) are able to produce EPA and DHA only in very limited quantities, aquatic ecosystems serve as the main source of these physiologically important substances in the biosphere (Gladyshev et al., 2009, 2013, 2015). PUFAs synthesized by microalgae are ted through the food ehain to invertebrates and fish and are brought out to the land mainly through waterfowls and waterbirds and the emergence of amphibiotic insects. According to the available estimates, amphibiotic insects supply $240 \times 10^{6} \mathrm{~kg} \mathrm{year}^{-1}$ EPA+DHA on a global scale, and birds bring out $432 \times 10^{6} \mathrm{~kg} \mathrm{year}^{-1}$ (for comparison: humans take out $180 \times 10^{6} \mathrm{~kg}$ year ${ }^{-1} \mathrm{EPA}+\mathrm{DHA}$ from aquatic ecosystems at the expense of fishing) (Gladyshev et al., 2009).

Thus, waterfowls and waterbirds are a very important factor of organic-matter transport from aquatic to terrestrial ecosystems not only in the quantitative but also in the qualitative respect. Nevertheless, the data 
on the FA composition of the biomass of waterfowls and waterbirds are few and scattered in the literature. The FA composition of waterfowls and waterbirds has not yet been compared with that of terrestrial birds. Therefore, the goal of our work was to compare the FA composition in different waterfowl and waterbird species with birds that feed on the land. We checked the following hypothesis: the content of EPA and DHA in the biomass of waterfowls and waterbirds that directly consume the products of aquatic ecosystems must be higher than in birds that are terrestrial feeders.

\section{MATERIALS AND METHODS}

\section{Research Areas}

Various bird species were caught in different years in the following areas. Chistoe Lake (the Gorky Reservoir Basin, Yaroslavl oblast), June-August 2008: gray heron (Ardea cinerea Linnaeus; the number of individuals taken for analysis was $n=9$ ); the Baraba forest steppe (the Novosibirsk oblast), July-August 2009: yellow wagtail (Motacilla flava Linnaeus, $n=1$ ), common tern (Sterna hirundo Linnaeus, $n=1$ ), barn swallow (Hirundo rustica Linnaeus, $n=1$ ), heron (A. cinerea, $n=1$ ), white wagtail (Motacilla alba Linnaeus, $n=1$ ), and oriental turtle dove (Streptopelia orientalis Latham, $n=1)$; the Lantsug and Chernavka Rivers (Elton Lake Basin, Volgograd oblast), August 2010 and 2014: common greenashank (Tringa nebularia Gunnerus, $n=1$ ), red-necked phalarope (Phalaropus lobatus Linnaeus, $n=1)$, great crested grebe (Podiceps cristatus Linnaeus, $n=1$ ), pied avocet (Recurvirostra avosetta Linnaeus, $n=1$ ), common shelduck (Tadorna tadorna Linnaeus, $n=1$ ), and Kentish plover (Charadrius alexandrinus Linnaeus, $n$ $=1$ ); the Kulunda steppe (the Novosibirsk oblast), July-September 2012: tree sparrow (Passer montanus Linnaeus, $n=8$ ), reed bunting (Emberiza schoeniclus Linnaeus, $n=3$ ), sedge warbler (Acrocephalus schoenobaenus Linnaeus, $n=2$ ), common starling (Sturnus vulgaris Linnaeus, $n=2$ ), rock dove (Columba livia Gmelin, $n=2$ ), white wagtail (M. alba, $n=1$ ), and black-headed gull (Larus ridibundus Linnaeus, $n=1$ ).

\section{Sampling}

Samples were taken for subsequent analyses of FAs from pectoral muscles, i.e., the tissue that is the basis of the edible bird biomass. Muscle samples weighing $0.5-1 \mathrm{~g}$ were fixed immediately after being taken with the chloroform: methanol mixture (the volume ratio of $2: 1$ ) and then kept at $-20^{\circ} \mathrm{C}$ up to further treatment for no more than a month. The biochemical analysis of FAs was made by the methods and under the conditions described earlier (Gladyshev et al., 2014).
Lipids were extracted from the samples with chloroform and methanol in the ratio of $2: 1$. Methanolysis of FAs of total lipids (i.e., the formation of methyl esters) was performed in a water bath at $85^{\circ} \mathrm{C}$ for $2 \mathrm{~h}$. Methyl esters of FAs were analyzed by a gas chromatograph equipped with a mass spectrometer detector (model 6890/5975C, Agilent Technologies, United States). The conditions of the analysis were as follows: helium was used as a carrier gas; entry was performed with dividing the steam; a HP-FFAP capillary column with a length of $30 \mathrm{~m}$ and internal diameter of $0.25 \mathrm{~mm}$ was used; the temperature of entry and interface was 250 and $280^{\circ} \mathrm{C}$, respectively; the ionization energy of the detector was $70 \mathrm{eV}$; and scanning was performed in the range of 45-450 atomic units. Chromatographic peaks of FAs were identified by mass spectra in comparison with those available in the NIST-2005 Database (Agilent Technologies), as well as by comparison of the retention times with those of the standards (Sigma, United States). The quantitative content of FAs in the biomass was determined according to the value of the internal standard nonadecanoic acid (19:0), a fixed amount of which was added to the samples before extracting lipids.

In the subsequent calculations, the total amount of $\mathrm{n}-3$ FAs consisted of the following acids: $18: 3 \mathrm{n}-3+$ $18: 4 n-3+20: 3 n-3+20: 5 n-3+22: 5 n-3+22: 6 n-3$. The total amount of $n-6$ FAs consisted of the following acids: $18: 2 n-6+18: 3 n-6+20: 2 n-6+20: 3 n-6+$ $20: 4 n-6+22: 4 n-6+22: 5 n-6$.

\section{Statistical Analysis}

The values of standard errors in mean were calculated as follows. The variance analysis accompanied by the post-hoc Fisher test calculation for the least significant differences (LSDs) was used to determine the significance of differences. The canonical correspondence analysis was also used to process data (the method of multivariate classification that permits multidimensional data (from the table) to be reduced to the least number of measurements (factors), under which the distances (variance) between individual cells (rows and columns) are shown in the "khisquare" values defined as an analogue of inertia (Legendre and Legendre, 1998). The calculations were all performed using the standard Statistica software package (version 9, StatSoft, Inc., Tulsa, OK, United States).

\section{RESULTS}

The totality of samples was detected to contain 79 FAs. The levels (the percentage of the total amount of acids) of quantitatively significant FAs are shown in Tables 1 and 2. The levels of short-chain FAs (12:0 and 14:0) varied insignificantly in the studied species. However, in Columbiformes, $S$. orientalis, and C. livia, 12:z was not found, and 14:0 and 16:0 had the 


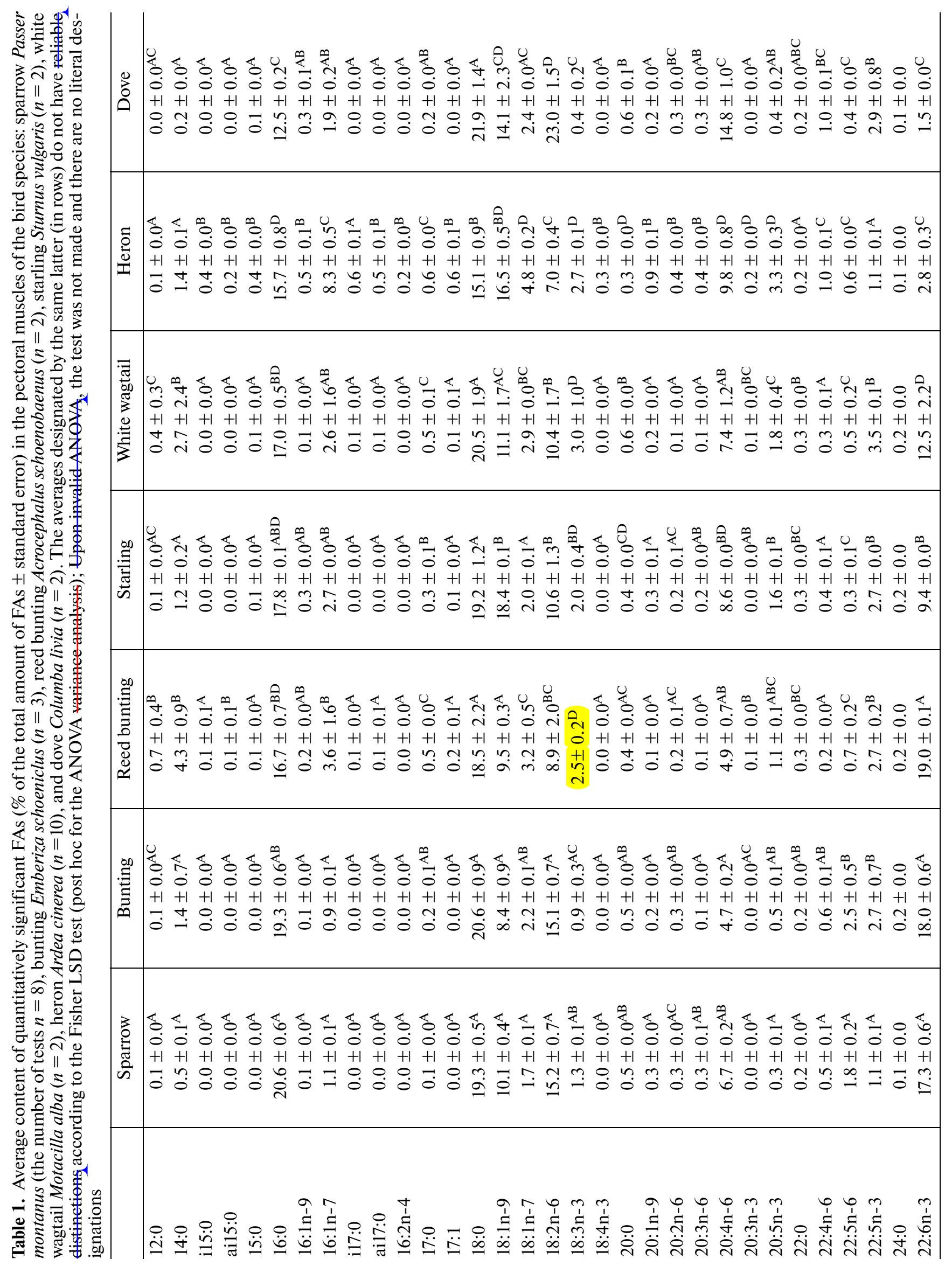

CONTEMPORARY PROBLEMS OF ECOLOGY Vol. 9 No.4 2016 


\begin{tabular}{|c|c|c|}
\hline \multicolumn{3}{|r|}{$\vec{i}$} \\
\hline 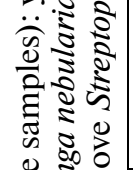 & 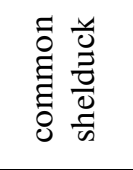 & 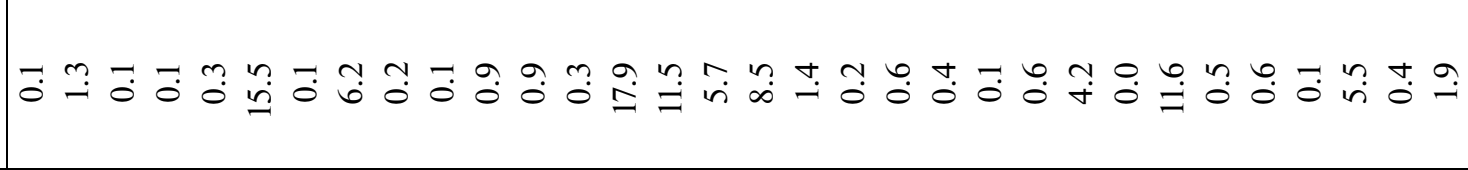 \\
\hline 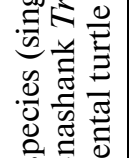 & 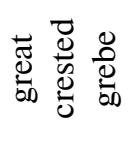 & 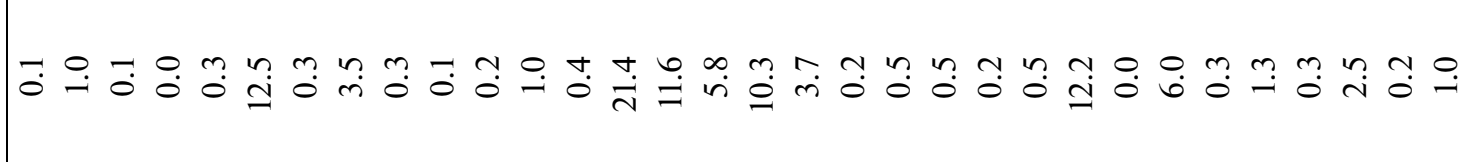 \\
\hline 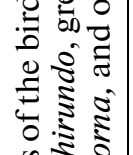 & E् & 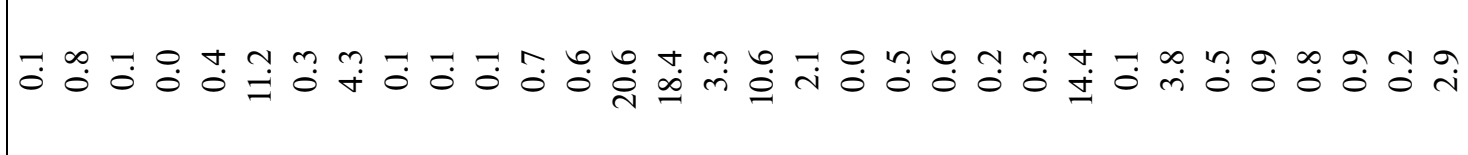 \\
\hline 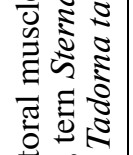 & $\frac{\overline{0}}{\frac{0}{2}}$ & 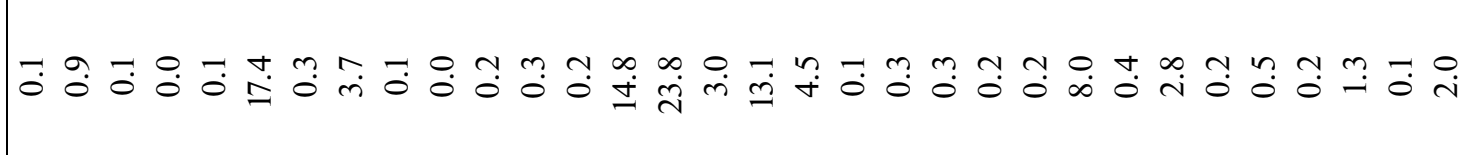 \\
\hline 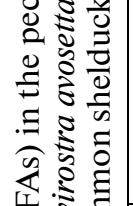 & 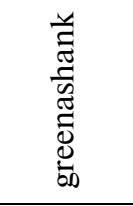 & 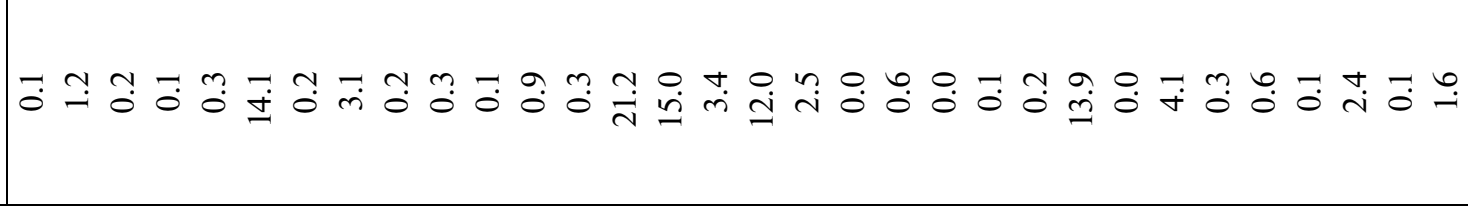 \\
\hline 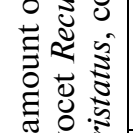 & E & 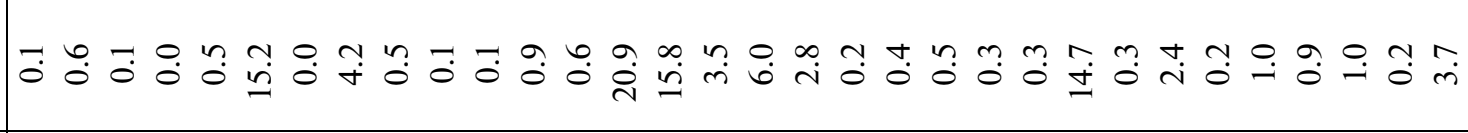 \\
\hline 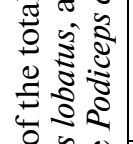 & 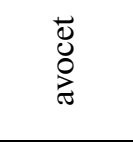 & 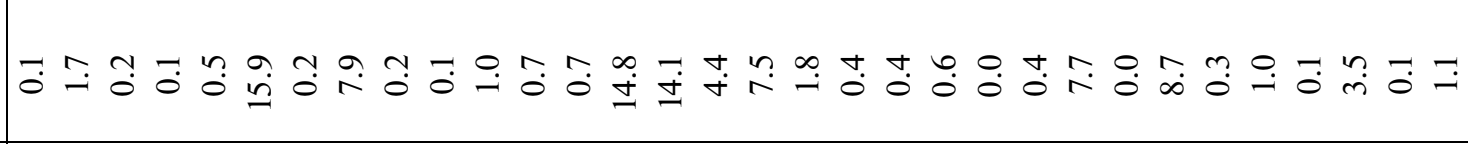 \\
\hline 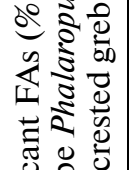 & 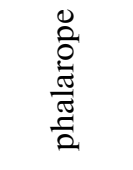 & 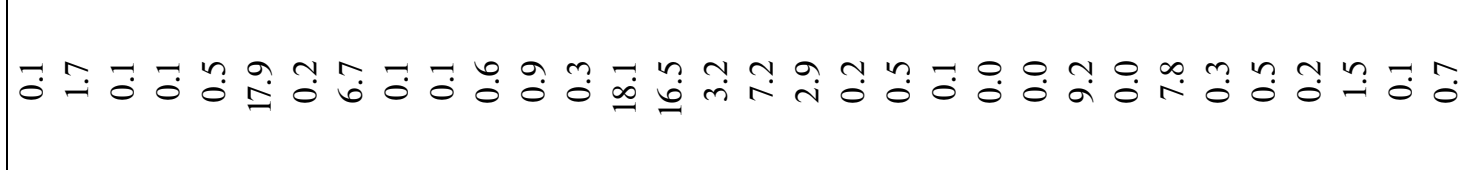 \\
\hline 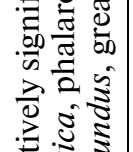 & $\frac{z}{\bar{z}}$ & 垈 \\
\hline 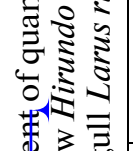 & 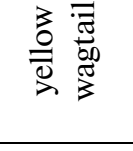 & 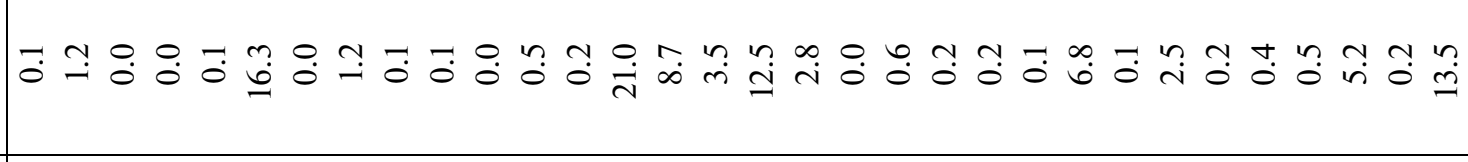 \\
\hline 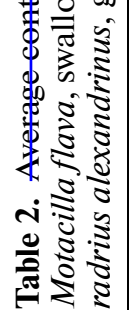 & & 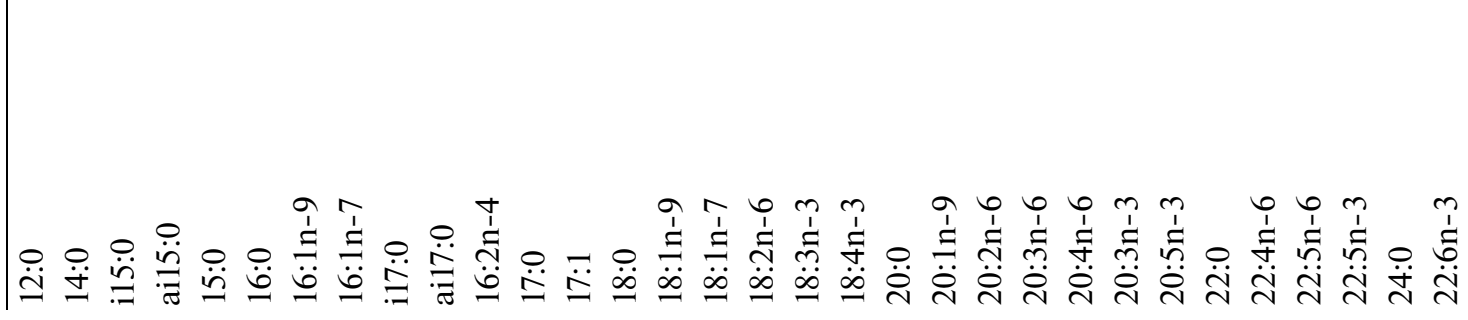 \\
\hline
\end{tabular}


minumum level (Tables 1, 2). FAs with a branched chain (iso-acids) and with an odd number of atoms (i15:0, ai15:0, 15:0, i17:0, ai17:0, 17:0, and 17:1) had the maximum levels (in sum, from 1.9 to $4.8 \%$ ) in $A$. cinerea, $P$. cristatus, $T$. tadorna and Charadriiformes (P. lobatus, $R$. avosetta, $S$. hirundo, T. nebularia and L. ridibundus) (Tables 1,2$)$. Among unsaturated acids, we should note the absence of $16: 2 n-4$ and $18: 4 n-3$ in all representatives of the Passeriformes order ( $P$. montanus, E. schoeniclus, A. schoenobaenus, S. vulgaris, M. alba, M. flava and $H$. rustica) and the Columbiformes order $(S$. orientalis and $C$. livia) (Tables 1, 2). Essential alpha-linolenic (18:3n-3, ALA) also had the maximal level in $S$. orientalis, but its minimum level was noted for C. livia (Tables 1, 2). The level of physiologically important docosahexaenoic acid was the highest among the representatives of the Passeriformes order: from $8.8 \%$ in $H$. rustica to $19.0 \%$ in A. schoenobaenus, whereas it was only from $0.7 \%$ (P. lobatus) to $3.7 \%$ ( $S$. hirundo) in the representatives of other orders (Tables 1,2). The levels of other acids, including oleic acid (18:1n-9, OA), arachidonic acid (20:4n-6, ARA), and eicosapentaenoic acid, varied without any obvious regularities both within the studied orders and between them (Tables 1, 2).

The multidimensional canonical correspondence analysis in the space of two canonical factors resulted in marking out the cluster including the species of Passeriformes order, the cluster formed by the species of the Columbiformes order, and the cluster including all other studied species (Fig. 1). The first canonical factor that shows $49.2 \%$ of the total variance (inertia) was caused primarily by the differences between the levels of 16:2n-4 and 18:4n-3, as well as iso- and odd FAs in waterfowls and waterbirds and the level of 22:6n-3 in Passeriformes and other species (Fig. 1). The second canonical factor that shows $17.5 \%$ of inertia was caused mainly by the differences in the levels of $18: 3 n-$ 3 and 18:2n-6 and level of 12:0 in Columbiformes and other birds (Fig. 1).

The content of two physiologically important polyunsaturated FAs EPA and DHA in the wet weight is presented in Table 3 . The maximum values of the content of EPA were found in Charadriiformes. In addition, the high $(>1 \mathrm{mg} / \mathrm{g})$ values of the content of EPA were found in T. tadorna (Anseriformes) and P. cristatus (Podicipediformes) (Table 3 ). The maximum values of the content of DHA proved to be a distinctive feature of Passeriformes (Table 3). The studied species were all detected to have the low values of the ratio between the sums of FAs n-6/n-3, except for $C$. livia (Table 3).

\section{DISCUSSION}

The conducted research studied the FA content and composition in two major groups of birds, namely aquatic and terrestrial feeders. The first group included waterfowls and waterbirds, the major food of which is aquatic invertebrates, amphibians, and fish: phalarope P. lobatus (Rubega and Inouye, 1994), pied avocet $R$. avosetta (Goutner, 1985), tern $S$. hirundo (Bugoni and Vooren, 2004; Danhardt et al., 2011), greenashank T. nebularia (Kalejta, 1993), plover C. alexandrinus (Castro et al., 2009; Pedro and Ramos, 2009), gull L. ridibundus (Moreira, 1995; Kubetzki and Garthe, 2003), shelduck T. tadorna (Anders et al., 20090; Ferns and Reed, 2009), great crested grebe P. cristatus (Gwiazda, 1997; Gagliardi et al., 2007), and heron A. cinerea (Fasola and Cardarelli, 2015). The second group consisted of birds, the diet which contains terrestrial plant and animal foods in different ratios: warbler $A$. schoenobaenus (Bibby et al., 1976. Schaub and Jenni, 2001; Zając and Solarz, 2004; Surmacki, 2005], sparrow P. montanus (Sakurai, 2011), swallow H. rustica (Orłowski and Karg, 2013; Orłowski et al., 2014), yellow wagtail M. flava (Gilroy et al., 2009), bunting E. schoeniclus (Orłowski et al., 2013), starling $S$. vulgaris (Rhymer et al., 2012), oriental turtle dove $S$. orientalis (Nakamura and Matsuoka, 1987), and rock dove C. livia (Baldaccini et al., 2000). White wagtail M. alba is able to feed with both adult terrestrial insects, including flying insects, and aquatic insect larvae and pupae, getting them near the water edge (Davies, 1976), so this species should be regarded as an intermediate between the two discussed bird groups.

As a result of the multidimensional canonical correspondence analysis, the group of waterfowls and waterbirds was separated from the "terrestrial" group. However, contrary to the original hypothesis, the main factors of this separation of the species in the multidimensional space were not EPA and DHA, but the 16:2n-4 marker of diatomaceens algae and bacterial acids with an odd number of carbon atoms and a branched carbon chain. Moreover, the group of birds with terrestrial feeding objects (Passeriformes) was separated from other species by the high level of DHA.

The high $(>20 \%)$ level of DHA in Passeriformes had been noted earlier in some works (Klaiman et al., 2009; Rodríguez-Turienzo et al. 2010); however, no comparison with other bird groups had been made, and the quantitative content in biomass had not been determined. The quantitative content of DHA in the biomass of Passeriformes was measured by us for the first time, and the high values were a complete surprise. As was noted above, most of the studied species from this order are mainly insectivorous, and among them only white wagtail $M$. alba gets part of its food (larvae and pupae) from water (riverside sludge). The content of DHA in the biomass in the discussed species from the Passeriformes order was from 1.5 to $3.5 \mathrm{mg} \mathrm{g}^{-1}$ weight; i.e., it largely surpassed the one not only in the waterfowls and waterbirds from the Charadriiformes, Anseriformes, Podicipediformes, and Ciconiiformes orders, but also in many fish species (Gladyshev et al., 2013). 

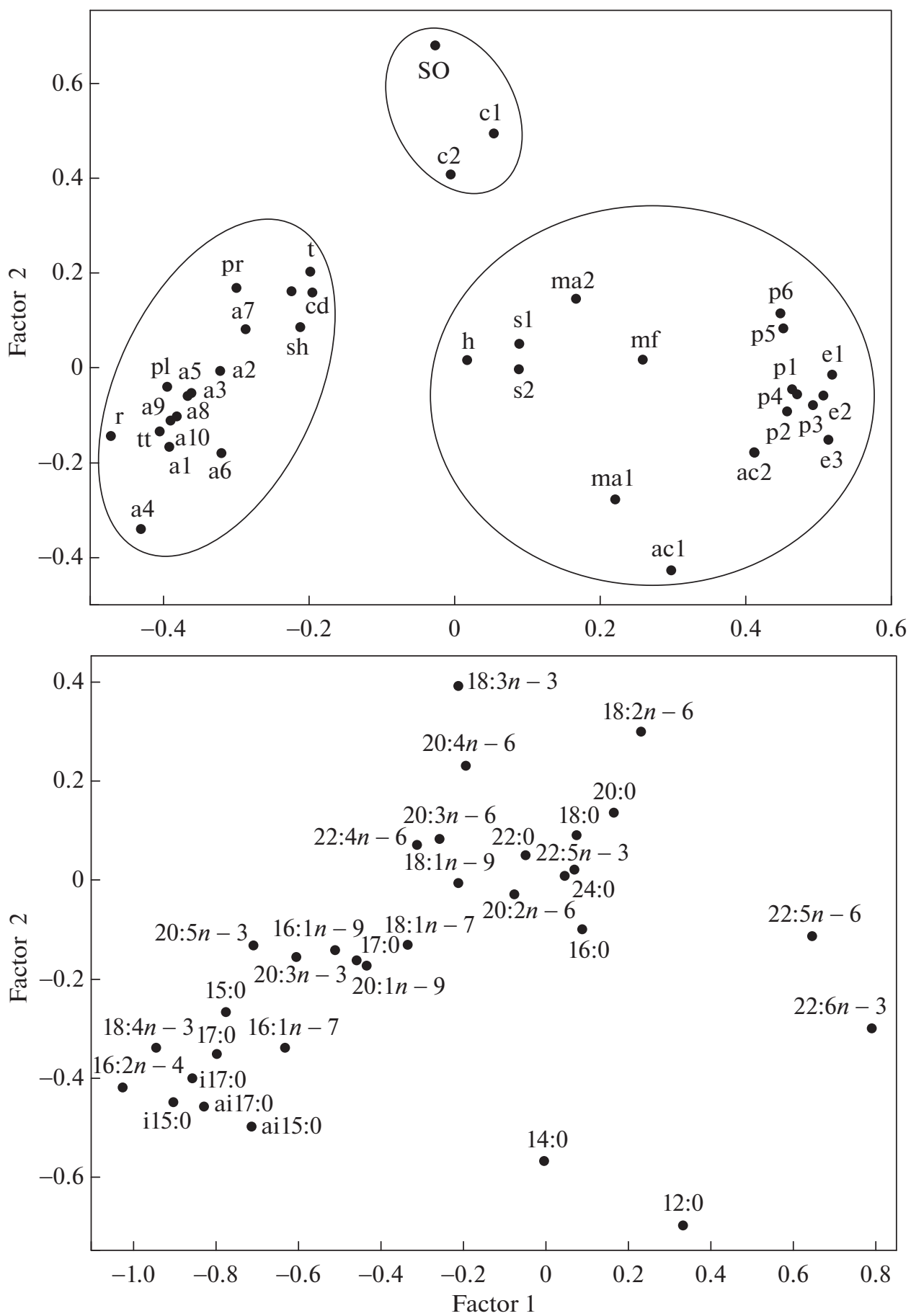

Canonical analysis of the correspondence between bird species and their fatty acid composition: ac, sedge warbler (Acrocephalus schoenobaenus); p, tree sparrow (Passer montanus); h, barn swallow (Hirundo rustica); mf, yellow wagtail (Motacilla flava); ma, white wagtail (Motacilla alba); e, reed bunting (Emberiza schoeniclus); s, common starling (Sturnus vulgaris); pl, Red-necked phalarope (Phalaropus lobatus); r, pied avocet (Recurvirostra avosetta); sh, common tern (Sterna hirundo); t, common greenashank (Tringa nebularia); cd, Kentish plover (Charadrius alexandrinus); 1, black-headed gull (Larus ridibundus); pr, great crested grebe (Podiceps cristatus); tt, common shelduck (Tadorna tadorna); a, gray heron (Ardea cinerea); so, oriental turtle dove (Streptopelia orientalis); and c, rock dove (Columba livia). Ciphers designate the numbers of samples taken in several replications.

What is the source of DHA in the biomass of Passeriformes? As was noted above, the basis of their diet is insects. However, as is known, terrestrial insects contain neither DHA nor EPA (Ryan et al., 1982;
Buckner and Hagen, 2003; Wang et al. 2006). Along with terrestrial insects, the studied Passeriformes species also consume imagoes of amphibiotic insects (Karpenko and Chernyshov, 1981; Prokofyeva, 2004; 
Table 3. Content eicosapentaenoic acid (EPA) and docosahexaenoic acid (DHA) $\left(\mathrm{mg} \mathrm{g}^{-1}\right.$ wet weight) in the pectoral muscles of birds from natural habitats. Ranking was made based on the maximum value of the EPA + DHA sum in orders

\begin{tabular}{|c|c|c|c|c|}
\hline Species & EPA & DHA & Sum & $n-6 / n-3$ \\
\hline \multicolumn{5}{|c|}{ Passeriformes } \\
\hline Sedge warbler (Acrocephalus schoenobaenus) & 0.2 & 3.5 & 3.7 & 0.6 \\
\hline Tree sparrow (Passer montanus) & 0.0 & 2.8 & 2.8 & 1.3 \\
\hline Barn swallow (Hirundo rustica) & 0.3 & 2.4 & 2.7 & 1.3 \\
\hline Yellow wagtail (Motacilla flava) & 0.4 & 2.3 & 2.7 & 0.9 \\
\hline White wagtail (Motacilla alba) & 0.3 & 1.8 & 2.5 & 0.9 \\
\hline Reed bunting (Emberiza schoeniclus) & 0.1 & 2.4 & 2.5 & 1.1 \\
\hline Common starling (Sturnus vulgaris) & 0.3 & 1.5 & 1.8 & 1.3 \\
\hline \multicolumn{5}{|c|}{ Charadriiformes } \\
\hline Red-necked phalarope (Phalaropus lobatus) & 2.1 & 0.2 & 2.3 & 1.3 \\
\hline Pied avocet (Recurvirostra avosetta) & 2.0 & 0.2 & 2.2 & 1.1 \\
\hline Common tern (Sterna hirundo) & 0.4 & 0.7 & 1.1 & 2.2 \\
\hline Common greenashank (Tringa nebularia) & 0.8 & 0.3 & 1.1 & 2.5 \\
\hline Kentish plover (Charadrius alexandrinus) & 0.5 & 0.4 & 0.9 & 2.0 \\
\hline Blach-headed gull (Larus ridibundus) & 0.5 & 0.4 & 0.9 & 2.8 \\
\hline \multicolumn{5}{|c|}{ Anseriformes } \\
\hline Common shelduck (Tadorna tadorna) & 1.6 & 0.3 & 1.9 & 0.7 \\
\hline \multicolumn{5}{|c|}{ Podicipediformes } \\
\hline Great crested grebe (Podiceps cristatus) & 1.3 & 0.2 & 1.5 & 1.9 \\
\hline \multicolumn{5}{|c|}{ Ciconiiformes } \\
\hline Gray heron (Ardea cinerea) & 0.6 & 0.6 & 1.2 & 1.9 \\
\hline \multicolumn{5}{|c|}{ Columbiformes } \\
\hline Rock dove (Columba livia) & 0.3 & 0.2 & 0.5 & 1.5 \\
\hline Oriental Turtle Dove (Streptopelia orientalis) & 0.1 & 0.2 & 0.3 & 8.2 \\
\hline
\end{tabular}

Chernyshov, 1981; Zając and Solarz, 2004; Gilroy et al., 2009), among which a special role is given to dragonflies. For example, Odonata (mainly, Sympetrum spp.) account for $64.2 \%$ of the total feed in the diet of yellow wagtail (Karpenko and Chenyshov, 1981; Chernyshov, 1981); in sum, the diet of Passeriformes was found to include representatives of nine genera, six families, and two suborders (Zygoptera and Anisoptera) of dragonflies (Prokofyeva, 2004). Nevertheless, amphibiotic insects contain a very small amount of DHA (Gladyshev et al., 2011; Sushchik et al., 2013). We can only assume that the species of the Passeriformes order have the ability to synthesize large amounts of DHA from essential alpha-linolenic acid (18:3n-3, ALA) and from EPA, which is quite rare among animals. ALA is contained in a large quantity in some terrestrial insects on which Passeriformes feed, for example, in butterflies (Wang et al. 2006; Sakurai, 2011). In turn, imagoes of amphibiotic insects (including dragonflies), which are also contained in the diet of Passeriformes, contain a lot of EPA (Gladyshev et al, 2011; Sushchik et al., 2013).

The physiological and biochemical significance of the high content of DHA in the pectoral muscles of Passeriformes is not quite clear. DHA is known to be the main component of phospholipids of the membranes of retinal cells and cells of the cerebral cortex; i.e., it plays the main role in the functioning of the organs of vision and nervous system (Lauritzen et al., 2001; SanGiovanni and Chew, 2005; Bazan, 2009). Indeed, it was experimentally established that the ability of nestlings to learn to peck useful food and avoid 
harmful food decreased at a low content of n-3 PUFAs in the diet of the mother (Fronte et al., 2008). At the same time, there is a well-known hypothesis about the "membrane eentrelofmetabelic rate" that is based on the inverse allometric correlation between the content of DHA in different tissues, including muscles of vertebrates and body size (Hulbert, 2007; Pierce and McWilliams, 2014). Warm-blooded animals with a relatively small body weight, such as most Passeriformes, are characterized by high values of metabolic rate (i.e., the amount of oxygen consumed per unit time per unit body weight) (Londono et al., 2015). In turn, the high content of DHA in metabolically active membranes of small warm-blooded animals was shown to ensure the high rate of the work of "energy" enzymes-transmembrane ion pumps with the ATP synthase activity (Wu et al., 2004; Hulbert, 2007). Thus, the content of DHA in the pectoral tissues of Passeriformes may reflect a relatively high metabolic rate in these animals. It should be noted that the extremely high accumulation of DHA in the pectoral muscles of Passeriformes in comparison with other orders for the purpose of ensuring the necessary metabolic rate takes place at the expense of its own synthesis rather than at the expense of food sources.

Along with seven representatives of the Passeriformes order, our study involved another order with a relatively small number of species (six): Charadriiformes. In the representatives of the Charadriiformes order, which we studied, the levels of EPA and DHA varied within $2.4-8.7 \%$ and $0.9-2.4 \%$, respectively. Meanwhile, according to the literature, the levels of EPA and DHA in the Artic sea birds from the Charadriiformes order varied from 3.6 to 14.2 and from 2.5 to $9.0 \%$, respectively (Wold et al., 2011); i.e., they on average largely surpassed those in the Charadriiformes that live or feed in the migration period at freshwater and satty lakes and rivers. In the studied birds of the Charadriiformes order, the amounts of FAs of n-6 family, namely, essential linoleic acid and arachidonic acid, were $6.0-13.1 \%$ and $8.0-14.7 \%$, respectively, whereas in the sea birds of the same order the amounts of LA and ARA varied within 3.3-4.8\% and 4.3$10.1 \%$, respectively (Wold et al., 2011). Therefore, lake and river Charadriiformes on average had higher levels of LA and ARA than sea Charadriiformes.

Based on the example of freshwater and marine semi-aquatic and aquatic mammals, it was shown that the level of n- 6 acids in the biomass of freshwater species was higher due to a large contribution of terrestrial food sources (Koussoroplis et al., 2008). It was suggested that the contribution of terrestrial food sources should be determined using the DHA/LA ratio, which proved to be much higher in marine mammals than in freshwater ones (Koussoroplis et al., 2008). The results of our studies permit the abovementioned ideas to be extended to birds. Moreover, the DHA/LA ratio in the Charadriiformes we studied varied within $0.10-0.61$, whereas this ratio in marine species was $0.69-2.57$ (we made the calculation based on the data of Wold et al., 2011). However, it should also be noted that the higher level of ARA in birds may be due not only to the contribution of terrestrial food sources, but also to the larger share of animal foods in their diet (Ramirez et al., 2009). In addition, the level of ARA in bird muscles may also depend on the properties of thermoregulation processes (Ben-Hamo et al., 2014).

The arguments and comparisons presented above are based on the levels of some FAs in bird tissues, which were expressed as a percentage of their total amount. However, in analyzing the trophic interactions in ecosystems, it is important to know the quantitative content of FAs in biomass rather than their levels. Unfortunately, the quantitative data on the content of FAs per unit of biomass of wild birds, which require the use of the internal standard in chromatography, are very scarce in the literature. Therefore, we can only compare the quantitative values of the content of EPA and DHA, which we established, with the data of one work. The published content of EPA and DHA in pectoral muscles was $0.023 \mathrm{mg} \mathrm{g}^{-1}$ and $0.437 \mathrm{mg} \mathrm{g}^{-1}$ in pheasant Phasianus colchicus (the Galliformes order), $0.495 \mathrm{mg} \mathrm{g}^{-1}$ and $0.387 \mathrm{mg} \mathrm{g}^{-1}$ in bald-coot Fulica atra (the Gruiformes order), and $0.258 \mathrm{mg} \mathrm{g}^{-1}$ and $0.261 \mathrm{mg} \mathrm{g}^{-1}$ raw weight in mallard Anas platyrhynchos (the Anseriformes order), respectively (Nuernberg et al., 2011). On the whole, the values of the content of EPA and DHA obtained in our study proved to be comparable with the published data given above.

In recent years, when discussing the problem of the relationship between the influence of dietary and genetic factors on the FA composition of animals, researchers have been giving more and more evidence to support the leading role of the genotype (species identity) (Makhutova et al., 2011; Gladyshev et al, 2012.; Lau et al., 2012). Our work has also showed that the FA composition of an individual taxon-the Passeriformes order-reliably differs from the one in birds of all other orders. Moreover, contrary to the initially proposed hypothesis, the highest biomass content of DHA was typical for the Passeriformes species that consume mostly terrestrial food, which is almost devoid of this FA. In contrast, waterfowls and waterbirds from other orders that consume aquatic biota, which is rich in DHA, contained a reliably smaller amount of DHA in their biomass than Passeriformes.

\section{ACKNOWLEDGMENTS}

This work was supported by the State Task of the Ministry of Education and Science of the Russian Federation to the Siberian Federal University to conduct research no. 6.1089.214/K; by the State Task within the Program of Fundamental Research of the Russian Federation, Themes no. 51.1.1 and VI.51.1.9; 
and grants from the Russian Foundation for Basic Research no. 13-04-00860 and 13-04-00740.

\section{REFERENCES}

Anders, N.R., Churchyard, T., and Hiddink, J.G., Predation of the shelduck Tadorna tadorna on the mud snail Hydrobia ulvae, Aquat. Ecol., 2009, vol. 43, pp. 11931199.

Arts, M.T., Ackman, R.G., and Holub, B.J., "Essential fatty acids" in aquatic ecosystems: a crucial link between diet and human health and evolution, Can. J. Fish. Aquat. Sci., 2001, vol. 58, pp. 122-137.

Baldaccini, N.E., Giunchi, D., Mongini, E., and Ragionieri, L., Foraging flights of wild rock doves (Columba l. livia): a spatio-temporal analysis, Ital. J. Zool., 2000, vol. 67 , pp. $371-377$.

Ballinger, A. and Lake, P.S., Energy and nutrient fluxes from rivers and streams into terrestrial food webs, Mar. Freshwater Res., 2006, vol. 57, pp. 15-28.

Baxter, C.V., Fausch, K.D., and Saunders, W.C., Tangled webs: reciprocal flows of invertebrate prey link streams and riparian zones, Freshwater Biol., 2005, vol. 50, pp. 201-220.

Bazan, N.G., Cellular and molecular events mediated by docosahexaenoic acid-derived neuroprotectin D1 signaling in photoreceptor cell survival and brain protection, Prostaglandins, Leukotrienes Essent. Fatty Acids, 2009, vol. 81, pp. 205-211.

Ben-Hamo, M., McCue, M.D., Khozin-Goldberg, I., McWilliams, S.R., and Pinshow, B., Ambient temperature and nutritional stress influence fatty acid composition of structural and fuel lipids in Japanese quail (Coturnix japonica) tissues, Comp. Biochem. Physiol., Part A: Mol. Integr. Physiol., 2013, vol. 166, pp. 244250.

Bibby, C.J., Green, R.E., Pepler, G.R.M., and Pepler, P.A., Sedge warbler migration and reed aphids, $B r$. Birds, 1976, vol. 69, pp. 384-399.

Buckner, J.S. and Hagen, M.M., Triacylglycerol and phospholipid fatty acids of the silverleaf whitefly: composition and biosynthesis, Arch. Insect Biochem. Physiol., 2003, vol. 53, pp. 66-79.

Bugoni, L. and Vooren, C.M., Feeding ecology of the Common Tern Sterna hirundo in a wintering area in southern Brazil, Ibis, 2004, vol. 146, pp. 438-453.

Castro, M., Masero, J.A., Pérez-Hurtado, A., Amat, J.A., and Megina, C., Sex-related seasonal differences in the foraging strategy of the Kentish plover, Condor, 2009, vol. 111 , pp. $624-632$.

Chernyshov, V.M., Comparative ecology of yellow and citrine wagtails in common habitats of Northern Kazakhstan and Baraba, in Ekologiya i biotsenoticheskie svyazi pereletnykh ptits Zapadnoi Sibiri (Ecology and Biocoenotic Relationships of Migrating Birds in Western Siberia), Novosibirsk: Nauka, 1981, pp. 138-160.

Danhardt, A., Fresemann, T., and Becker, P.H., To eat or to feed? Prey utilization of common terns Sterna hirundo in the Wadden Sea, J. Ornithol., 2011, vol. 152, pp. $347-357$.
Davies, N.B., Food, flocking, and territorial behavior of the pied wagtail (Motacilla alba yarrellii Gould) in winter, J. Anim. Ecol., 1976, vol. 45, pp. 235-253.

Fasola, M. and Cardarelli, E., Long-term changes in the food resources of a guild of breeding Ardeinae (Aves) in Italy, Ital. J. Zool., 2015, vol. 82, no. 2, pp. 238-250.

Ferns, P.N. and Reed, J.P., Effects of the Cardiff Bay tidal barrage on the abundance, ecology and behavior of shelducks Tadorna tadorna, Aquat. Conserv. Mar. Freshwater Ecosyst., 2009, vol. 19, pp. 466-473.

Fronte, B., Paci, G., Montanari, G., and Bagliacca, M., Learning ability of 1-d-old partridges (Alectoris rufa) from eggs laid by hens fed with different n-3 fatty acid concentrations, Br. Poult. Sci., 2008, vol. 49, pp. 776780.

Gagliardi, A., Martinoli, A., Preatoni, D., Wauters, L.A., and Tosi, G., From mass of body elements to fish biomass: a direct method to quantify food intake of fish eating birds, Hydrobiologia, 2007, vol. 583, pp. 213222.

Gilroy, J.J., Anderson, G.Q.A., Grice, P.V., Vickery, J.A., Watts, P.N., and Sutherland, W.J., Foraging habitat selection, diet and nestling condition in yellow wagtails Motacilla flava breeding on arable farmland, Bird Study, 2009, vol. 56, pp. 221-232.

Gladyshev, M.I., Arts, M.T., and Sushchik, N.N., Preliminary estimates of the export of omega-3 highly unsaturated fatty acids (EPA+DHA) from aquatic to terrestrial ecosystems, in Lipids in Aquatic Ecosystems, Arts, M.T., Brett, M.T., and Kainz, M., Eds., New York: Springer-Verlag, 2009, pp. 179-209.

Gladyshev, M.I., Kharitonov, A.Y., Popova, O.N., Sushchik, N.N., Makhutova, O.N., and Kalacheva, G.S., Quantitative estimation of dragonfly role in transfer of essential polyunsaturated fatty acids from aquatic to terrestrial ecosystems, Dokl. Biochem. Biophys., 2011, vol. 438, pp. 141-143.

Gladyshev, M.I., Lepskaya, E.V., Sushchik, N.N., Makhutova, O.N., Kalachova, G.S., Malyshevskaya, K.K. and Markevich, G.N., Comparison of polyunsaturated fatty acids content in filets of anadromous and landlocked sockeye salmon Oncorhynchus nerka, J. Food Sci., 2012, vol. 77, pp. C1306-C1310.

Gladyshev, M.I., Makhutova, O.N., Gubanenko, G.A., Rechkina, E.A., Kalachova, G.S., and Sushchik, N.N., Livers of terrestrial production animals as a source of long-chain polyunsaturated fatty acids for humans: an alternative to fish? Eur. J. Lipid Sci. Technol., 2015, vol. 117, pp. 1417-1421.

Gladyshev, M.I., Sushchik, N.N., and Makhutova, O.N., Production of EPA and DHA in aquatic ecosystems and their transfer to the land, Prostaglandins Other Lipid Mediators, 2013, vol. 107, pp. 117-126.

Gladyshev, M.I., Sushchik, N.N., Gubanenko, G.A., Kalachova, G.S., Rechkina, E.A., and Malyshevskaya, K.K., Effect of the way of cooking on contents of essential polyunsaturated fatty acids in filets of zander, Czech J. Food Sci., 2014, vol. 32, pp. 226-231.

Goutner, V., Breeding ecology of the avocet (Recurvirostra avosetta L.) in the Evros delta (Greece), Bonn. Zool. Beitr., 1985, vol. 36, pp. 37-50. 
Gratton, C. and Vander Zanden, M.J., Flux of aquatic insect productivity to land: comparison of lentic and lotic ecosystems, Ecology, 2009, vol. 90, pp. 26892699.

Gwiazda, R., Foraging ecology of the Great Crested Grebe (Podiceps cristatus L.) at a mesotrophic-eutrophic reservoir, Hydrobiologia, 1997, vol. 353, pp. 39-43.

Hulbert, A.J., Membrane fatty acids as pacemakers of animal metabolism, Lipids, 2007, vol. 42, pp. 811-819.

Kalejta, B., Diets of shorebirds at the Berg River estuary, South Africa: spatial and temporal variation, $J$. $A f r$. Ornithol., 1993, vol. 64, pp. 123-133.

Karpenko, S.V. and Chernyshov, V.M., Characteristics of infestation of yellow and citrine wagtails by worms related to their ecological peculiarities, in Ekologiya $i$ biotsenoticheskie svyazi pereletnykh ptits Zapadnoi Sibiri (Ecology and Biocoenotic Relationships of Migrating Birds in Western Siberia), Novosibirsk: Nauka, 1981, pp. 240-244.

Klaiman, J.M., Price, E.R., and Guglielmo, C.G., Fatty acid composition of pectoralis muscle membrane, intramuscular fat stores and adipose tissue of migrant and wintering white-throated sparrows (Zonotrichia albicollis), J. Exp. Biol., 2009, vol. 212, pp. 3865-3872.

Koussoroplis, A.M., Lemarchand, C., Bec, A., Desvilettes, C., Amblard, C., Fournier, C., Berny, P., and Bourdier, G., From aquatic to terrestrial food webs: decrease of the docosahexaenoic acid/linoleic acid ratio, Lipids, 2008, vol. 43, pp. 461-466.

Kubetzki, U. and Garthe, S., Distribution, diet and habitat selection by four sympatrically breeding gull species in the south-eastern North Sea, Mar. Biol., 2003, vol. 143, pp. 199-207.

Lau, D.C.P., Vrede, T., Pickova, J., and Goedkoop, W., Fatty acid composition of consumers in boreal lakes variation across species, space and time, Freshwater Biol., 2012, vol. 57, pp. 24-38.

Lauritzen, L., Hansen, H.S., Jorgensen, M.H., and Michaelsen, K.F., The essentiality of long chain n-3 fatty acids in relation to development and function of the brain and retina, Prog. Lipid Res., 2001, vol. 40, pp. 1-94.

Legendre, P. and Legendre, L., Numerical Ecology, Amsterdam: Elsevier, 1998.

Londono, G.A., Chappell, M.A., Castaneda, M.R., Jankowski, J.E., and Robinson, S.K., Basal metabolism in tropical birds: latitude, altitude, and the 'pace of life', Funct. Ecol., 2015, vol. 29, pp. 338-346.

Makhutova, O.N., Sushchik, N.N., Gladyshev, M.I., Ageev, A.V., Pryanichnikova, E.G., and Kalachova, G.S., Is the fatty acid composition of freshwater zoobenthic invertebrates controlled by phylogenetic or trophic factors? Lipids, 2011, vol. 46, pp. 709721.

Moreira, F., Diet of black-headed gulls Larus ridibundus on emerged intertidal areas in the Tagus estuary (Portugal): predation or grazing? J. Avian Biol., 1995, vol. 26, pp. $277-282$.

Nakamura, K. and Matsuoka, S., The feeding from edge towards inner part in soybean plot in rufous turtle dove, Streptopelia orientalis (Latham) and the estimation of passing rate of the flock, Res. Popul. Ecol., 1987, vol. 20, pp. 45-55.

Nakano, S. and Murakami, M., Reciprocal subsidies: dynamic interdependence between terrestrial and aquatic food webs, Proc. Natl. Acad. Sci. U.S.A., 2001, vol. 98, pp. 166-170.

Nuernberg, K., Slamecka, J., Mojto, J., Gasparik, J., and Nuernberg, G., Muscle fat composition of pheasants (Phasianus colchicus), wild ducks (Anas platyrhynchos) and black coots (Fulica atra), Eur. J. Wildl. Res., 2011, vol. 57, pp. 795-803.

Orłowski, G. and Karg, J., Diet breadth and overlap in three sympatric aerial insectivorous birds at the same location, Bird Study, 2013, vol. 60, pp. 475-483.

Orłowski, G., Karg, J., and Czarnecka, J., Substantial contribution of invertebrates to the diet of a winter seedeater, the reed bunting Emberiza schoeniclus, wintering in a sewage farm in south-western Poland, Biol. J. Linn. Soc., 2013, vol. 108, pp. 429-433. Orłowski, G., Karg, J., and Karg, G., Functional invertebrate prey groups reflect dietary responses to phenology and farming activity and pest control services in three sympatric species of aerially foraging insectivorous birds, PLoS One, 2014, vol. 9, no. 12, p. e114906. doi 10.1371/journal.pone.0114906

Pedro, P. and Ramos, J.A., Diet and prey selection of shorebirds on salt pans in the Mondego estuary, Western Portugal, Ardeola, 2009, vol. 56, pp. 1-11.

Pierce, B.J. and McWilliams, S.R., The fat of the matter: how dietary fatty acids can affect exercise performance, Integr. Comp. Biol., 2014, vol. 54, pp. 903-912.

Prokof'eva, I.V., The role of dragonflies Odonata in feeding the birds, Russ. Ornitol. Zh., 2004, vol. 13, no. 257, pp. 299-303.

Ramirez, F., Jover, L., Sanpera, C., Ruiz, X., Pique, E., and Guitart, R., Combined measurements of egg fatty acids and stable isotopes as indicators of feeding ecology in lake-dwelling birds, Freshwater Biol., 2009, vol. 54 , pp. $1832-1842$.

Ryan, R.O., De Renobales, M., Dillwith, J.W., Heisler, C.R., and Blomquist, G.J., Biosynthesis of myristate in an aphid: involvement of a specific acyithioesterase, Arch. Biochem. Biophys., 1982, vol. 213, pp. 26-36.

Rodríguez-Turienzo, L., Díaz, O., Sanmartín, B., and Cobos, A., Characterization of meat from two game birds: thrush (Turdus philomelos) and turtle dove (Streptopelia turtur), CyTA-J. Food, 2010, vol. 8, no. 3, pp. 209-215.

Rubega, M. and Inouye, C., Prey switching in red-necked phalaropes Phalaropus lobatus: feeding limitations, the functional response and water management at Mono Lake, California, USA, Biol. Conserv., 1994, vol. 70, pp. 205-210.

Rhymer, C.M., Devereux, C.L., Denny, M.J.H., and Whittingham, M.J., Diet of starling Sturnus vulgaris nestlings on farmland: the importance of Tipulidae larvae, Bird Study, 2012, vol. 59, pp. 426-436.

Sakurai, R., Field observation of predation on adult lepidopterans by the tree sparrow Passer montanus saturatusens, Entomol. Sci., 2011, vol. 14, pp. 162-165. 
SanGiovanni, J.P. and Chew, E.Y., The role of omega-3 long-chain polyunsaturated fatty acids in health and disease of the retina, Prog. Retinal Eye Res., 2005, vol. 24, pp. 87-138.

Schaub, M. and Jenni, L., Stopover durations of three warbler species along their autumn migration route, Oecologia, 2001, vol. 128, pp. 217-227.

Surmacki, A., Do dense and fast growing crops provide foraging habitats for insectivorous birds? Pol. J. Ecol., 2005, vol. 53, pp. 129-133.

Sushchik, N.N., Yurchenko, Y.A., Gladyshev, M.I., Belevich, O.E., Kalachova, G.S., and Kolmakova, A.A., Comparison of fatty acid contents and composition in major lipid classes of larvae and adults of mosquitoes (Diptera: Culicidae) from a steppe region, Insect Sci., 2013, vol. 20, pp. 585-600.

Wang, Y., Lin, D.S., Bolewicz, L., and Connor, W.E., The predominance of polyunsaturated fatty acids in the but- terfly Morpho peleides before and after metamorphosis, J. Lipid Res., 2006, vol. 47, pp. 530-536.

Wold, A., Jæger, I., Hop, H., Gabrielsen, G.W., and FalkPetersen, S., Arctic seabird food chains explored by fatty acid composition and stable isotopes in Kongsfjorden, Svalbard, Polar Biol., 2011, vol. 34, pp. 11471155.

Wu, B.J., Hulbert, A.J., Storlien, L.H. and Else, P.L., Membrane lipids and sodium pumps of cattle and crocodiles: an experimental test of the membrane pacemaker theory of metabolism, Am. J. Physiol., 2004, vol. 287, pp. R633-R641.

Zając, T. and Solarz, W., Low incidence of polygyny revealed in a long term study of the sedge warbler Acrocephalus schoenobaenus in natural wetlands of the Southern Poland, Acta Ornithol., 2004, vol. 39, pp. 83-86.

Translated by L. Solovyova

SPELL: 1. OK 